\title{
SOIL AND WATER MANAGEMENT PROGRAM IN MICRO-BASINS: A STUDY ON THE ENVIRONMENTAL, SOCIAL AND ECONOMIC ASPECTS
}

\author{
Sérgio Luís Dias Doliveira \\ Docente no Programa de Pós-Graduação Interdisciplinar em Desenvolvimento Comunitário \\ PPGDC/UNICENTRO, Nível Doutorado, Universidade Estadual do Centro-Oeste - UNICENTRO \\ Lotado no Departamento de Administração - DEADM/UNICENTRO - Campus de Irati-PR, Brasil \\ sldd@uol.com.br \\ Mauricio João Atamanczuk \\ Docente do Departamento de Administração, Nível Doutorado - DEADM/UNICENTRO \\ Campus de Irati-PR, Brasil \\ mauricioata@yahoo.com.br \\ Simone Soares \\ Mestre no Programa de Pós-Graduação Interdisciplinar em Desenvolvimento Comunitário \\ Universidade Estadual do Centro-Oeste - UNICENTRO- Campus de Irati -PR, Brasil. \\ simosoares@gmail.com \\ Luciane Silva Franco \\ Mestre no Programa de Pós-Graduação Interdisciplinar em Desenvolvimento Comunitário \\ Universidade Estadual do Centro-Oeste - UNICENTRO- Campus de Irati -PR, Brasil \\ luciane.unicentro@gmail.com \\ Hebron Mateus Freire Sanways \\ Graduação em Administração \\ Universidade Estadual do Centro-Oeste - UNICENTRO- Campus de Irati -PR, Brasi \\ hebronsanways@gmail.com \\ Élisson José Padilha \\ Graduação em Administração \\ Universidade Estadual do Centro-Oeste - UNICENTRO- Campus de Irati -PR, Brasil \\ elisson@gmail.com
}

\begin{abstract}
The paper seeks to investigate the environmental, social and economic impacts of the Soil and Water Management Program in Micro-basins in Paraná for farm producers participating in the program in the town of Irati/PR and region. The agency affirms that the initiative aims to generate a better quality of life for the residents near the micro-basins, as well as to help in the agricultural productive capacity of the region. The paper's results showed that $85 \%$ of the producers believe that the program not only fulfilled what it proposed but also entailed several positive points and significant changes in the relationship between rural producers and the work in the field. Thus, the program assumes an essential role in its condition of public policy, generating income, social welfare, and environmental protection in the Irati/PR region.
\end{abstract}

Palavras-chave: Sustainability. Environment. Micro-Basins.

\section{PROGRAMA DE GESTÃO DE SOLO E ÁGUA EM MICROBACIAS: UM ESTUDO ACERCA DOS ASPECTOS AMBIENTAIS, SOCIAIS E ECONÔMICOS}

\section{RESUMO}

O artigo busca investigar os impactos ambientais, sociais e econômicos do Programa de Gestão de Solo e Água em Microbacias do Paraná para os produtores rurais que participam do programa no município de Irati/PR e região. O órgão afirma que a iniciativa almeja gerar uma melhor qualidade de vida aos moradores próximos às microbacias, bem como, auxiliar na capacidade produtiva agrícola da região. O artigo apresentou como resultados que $85 \%$ dos produtores acreditam que o programa cumpriu o que propôs e que, além disso, trouxe também diversos pontos positivos e significativas mudanças na relação entre produtor rural e o trabalho no campo. Dessa forma, o programa assume um importante papel em sua condição de política pública, gerando renda, bem-estar social e proteção ambiental na região de Irati/PR.

Keywords: Sustentabilidade. Meio Ambiente. Microbacias.

$\begin{array}{lllll}\text { Caminhos de Geografia } \quad \text { Uberlândia-MG } & \text { v. 22, n. 83 } & \text { out./2021 } & \text { p. 104-117 Página } 104\end{array}$




\section{INTRODUCTION}

Sustainability encompasses solutions for the depletion of natural resources, aiming to use them continuously. It is a way of thinking and behaving in society that has become increasingly more mature over the last years (Adhami et al., 2020 and Mengistu; Assefa, 2019). Sustainable development involves adopting business activities and strategies that meet the needs of the organization and its stakeholders while protecting, supporting, and enhancing the social, environmental and economic resources that will be necessary for the future (Magalhães and Barp, 2014; Blackburn, 2007).

The scope of the theme sustainability allows us to study many different realities, among which is the preservation of water, one of the essential resources for life, where care is essential so that it is always within reach (Rhoden et al., 2016). Given this reality, it is necessary to work and carry out actions that in practice result in greater care for water resources, which is also present in the reality of many rural producers who seek to make their business more profitable, which in itself brings several benefits to the community.

Many of these social benefits come from projects and partnerships, such as the Soil and Water Management Program in Microbasins, one of the objectives of this program is precisely to work on the correct management of natural resources used by producers, including water (SEAB, 2018). Sustainable development in the universe of organizations, in general, still does not present a field for the development of scientific research (Stefano and Teixeira, 2014). Therefore, the studies that are carried out can contribute both with the existing theory and empirically to the topic in question.

This study focuses on the Soil and Water Management Program in Micro-basins, or simply Micro-basin Program. The project addresses a series of questions related to farm work and other rural activities, having the farm producer as one of the most important agents involved in the process.

According to the EMATER (2018), the Soil and Water Management Program in Micro-basins is an initiative of Paraná's state government that aims to maintain and recover natural resources. It intends to generate a better quality of life for the residents near the micro-basins, aid in the region's productive capacity, and attain the sustainability dimensions proposed by Elkington (1998). It is worth mentioning the considerable challenges encountered to put the program in action, including the acceptance of the community and other complex variables that need to be better understood to optimize the use of existing resources and improve the management of the program.

In order to encompass these new paths, the central purpose of this study was to investigate the environmental, social and economic impacts of the Soil and Water Management Program in Microbasins for farm producers participating in the program in the town of Irati/PR and region. Initially, the paper presents its theoretical framework, which focuses on comprehending the sustainable development perspective with emphasis on managing water resources and the projects and programs of soil and water management in micro-basins in Paraná. Subsequently, it presents the adopted methodology, followed by the main results and discussions about the findings.

\section{SUSTAINABLE DEVELOPMENT AND WATER RESOURCES}

The Brundtland Report defined sustainable development as one that meets the needs of the present without compromising the needs of future generations (CMMAD, 1991). The three pillars of sustainable development indicate social relevance, ecological prudence, and economic viability (Sachs, 2002).

Additionally, the institutional dimension is another key factor for sustainable development. The theme was addressed at Rio-92 (the United Nations Conference on Environment and Development - UNCED - that took place in Rio de Janeiro, 1992), aiming to alter the terms of governance, be it in the decisionmaking process, in personnel training, in the implementation of new public policies, or even in the sensible choice of individuals who will put in practice the new sustainability fundamentals (Camargo, 2003).

Blackburn (2007) seeks to illustrate that the concept of sustainability is not a fad. The author analyzes its history from the emergence of the concept in Stockholm in 1972 to 1999 when the Global Reporting Initiative (GRI) published its draft for the Sustainability Reporting Guidelines for organizations, which

$\begin{array}{lllll}\text { Caminhos de Geografia } & \text { Uberlândia-MG } & \text { v. 22, n. } 83 & \text { out./2021 } & \text { p. 104-117 Págin } 105\end{array}$


determined that sustainability involved all three elements of the triple bottom line. The final versions, published in 2000 and 2002, maintained that position.

Recurrently, the literature has focused on ascertaining up to which point the sustainable behavior of organizations and society compromises financial performance - and not the other way around. According to Maignan and Ralston (2002), sustainable behavior is one that does not ruin the local environment nor endangers the community's health, measured by internationally-accepted standards of environmental health or quality.

It is worth mentioning that the UNCED produced Agenda 21, a document that systematizes an action plan to achieve sustainable development (Barbieri, 2001). However, Novaes (2003) warns that Agenda 21 will not solve the economic, social, and environmental problems and that it is representative of the participation of all involved parts to comprehend and resolve the conflict demands aiming to build a broadened and progressive sustainability.

The influences of hydrographic basins on the environment are constant concerns of the community, which entails a rise in studies that analyze those impacts. The management of hydrographic basins is an indicative factor for observing the varying qualities of the soil and water. Tracking water quality provides empirical data that aids in the decision-making related to aspects concerning health and the environment (Silva and Silva, 2014). The plan of hydrographic basins is fundamental to provide a diagnosis for the formulation of goals in the environmental conservation and preservation for the entire population, reducing future difficulties concerning the proper use of water (Luiz et al., 2017).

\section{Management of Water Resources}

Hydrographic basins play a representative role as a natural and socioeconomic component, essential in ecosystemic services and the environmental, social, and economic security of society. However, the degradation of hydrographic basins has been an obstacle globally, which demands more attention, especially in developing countries (Adhami et al., 2020).

In the interim, it is worth mentioning the fundamentals of water management: planning, organization, direction, and assessment connect a broader vision, which allows a coordinated process of development and management of water resources. Thus, the main objective is to optimize the social and economic resources fairly, not compromising the sustainability of ecosystems (Magalhães and Baganha, 2014).

However, Tundisi (2003) points out a few complex problems concerning the quantity and quality of water resources in Brazil, which require significant institutional and technological advances, as well as new views towards preventive, integrated, and adaptive management. The author expands, stressing the importance of a systemic view that observes the capacity of an ecosystem in the long term without exceeding it.

Hydrographic basins have spatial expressiveness, constituting complex environmental systems in their structure, functioning, and evolution (Christofoletti, 1999). Magalhães and Baganha (2014) add that the basin, its natural resources and its inhabitants impose physical, biological, economic, social, and cultural conditions that grant characteristics specific to each one.

Carvalho et al. (2011) emphasize the need for analyzing Brazil's management system under a global lens, reassessing the technical skills of each specific organ of the National System of Water Resources, especially the state organs, so that they employ their technical skills efficiently and reliably.

\section{Development Programs and Projects}

Public investment projects and programs are usually formulated and have their priorities set based on proposals from the public sector. In larger countries, the planning occurs at small and medium scale, through regional programs applied especially in rural areas with the participation of non-governmental organizations (Potts, 2002).

Pfeiffer (2005) stresses that development projects are measures defined, planned and carried out with responsibility, within the deadlines and established resources. Therefore, programs are understood as elements of complex projects with a common management structure (Pfeiffer, 2005).

$\begin{array}{lllll}\text { Caminhos de Geografia } & \text { Uberlândia-MG } & \text { v. 22, n. } 83 & \text { out./2021 } & \text { p. 104-117 }\end{array}$


According to Attanasio (2012), it is essential to include a few strategies to development programs and projects, such as integration of social and environmental programs to community participation and technical committee; at least one micro-basin per town in each state acting in the conservation and handling of water and soil; training in public policy management; access to rural credit to maintain resources; and regional communities with technical bases available.

Thus, the administration of water resources needs to consider the contribution from civil society to improve its public policies, reinforcing environments of community participation through committees (Junior and Ferrão, 2018). As solutions, environmental education and developing a set of specific information directed at each hydrographic basin are fundamental because they would lead to a management system with greater predictability capacity (Silva and Silva, 2014).

\section{Soil and Water Management Program in Micro-Basins in Paraná}

The Soil and Water Management Program in Micro-basins is an action of Paraná's state government that aims to maintain and recover natural resources (EMATER, 2018). The organ affirms that the initiative intends to generate a higher quality of life for the residents near the micro-basins, as well as aid in the agricultural productive capacity of the region.

Data from the SEAB (2018) show that Paraná's agriculture is the second-highest exporter in the national agribusiness, representing over one-third of the sector's GDP and standing out in the production of corn, wheat, yerba mate, pine, potato, cassava, soy, sugar cane, tomato, coffee, pork, poultry, among others. This level of production impacts the economy, the environment, and the society as a whole. From the environmental point of view, for instance, the intensive use of the soil may generate unbalances, the excessive use of pesticides, problems with the forest cover, the neglect with the springs and basins in the region, among other relevant points that must be addressed with the rural producer $(S E A B, 2018)$.

The Program is structured so that three main components encompass all of the actions: Modernization of Rural Area Management, Education for Society, and Harmonization of Agricultural Production and Conservation of Natural Resources (Manual Operativo do Projeto, 2017). According to the manual, the first component's function is to enable the State, employing technicians responsible for inspecting, monitoring and implementing the Program's operational strategies, utilizing modern devices to optimize the decision-making based on the information obtained.

The second component, Education for Society, is conducted by the EMATER, aided by the State Secretariat of the Environment (Secretaria de Estado de Meio Ambiente - SEMA) and the State Secretariat of Education (Secretaria de Estado de Educação - SEED), with the optional participation of technicians from public and private institutions. It is responsible for showing to the families near the micro-basins the importance of preserving natural resources, allied to the resulting improved quality of life (Manual Operativo do Projeto, 2017).

Finally, the Project's Operative Manual (2017) presents the third component as a joint action with the producers. They have access to a workshop that exhibits the data related to their micro-basin, facilitating the comprehension of the actions that need to be carried out. Knowing the data, the producers must discuss the attitudes required for improving the sustainability of the region.

The Program reaches the entire state of Paraná, in a total of 250 micro-basins distributed in areas of agriculture and livestock raising that present problems of erosion and intensive use of pesticides, areas of highly-frail soil (Arenito Caiuá and the coast), areas that have demand for water, and areas that feature a significant number of agricultural families (Manual Operativo do Projeto, 2017). Still according to the manual, the Program focuses on rural residents that live around the micro-basins, in a total of about 25,000 families. Each micro-basin encompasses about 100 families, each one being focus of the Program regardless of their financial or productive capacity (Manual Operativo do Projeto, 2017).

$\begin{array}{lllll}\text { Caminhos de Geografia } & \text { Uberlândia-MG } & \text { v. 22, n. } 83 & \text { out./2021 } & \text { p. 104-117 Págin } 107\end{array}$




\section{Characterization of the Study Area}

The Três Rios Micro-basin is located within the town of Irati/PR (see Figure 1) and encompasses the communities Volta Grande, Mato Queimado and Campina de Gonçalves Júnior. It was one of the beneficiaries of the Soil and Water Management Program of Micro-basins (SEAB, 2018). The program is carried out in several regions of the State of Paraná, in this specific case, the reality investigated concerns the municipality of Irati and region, where agriculture is one of the most important economic activities, enriching regional and country production as a whole.

Figure 1 - Location of the Três Rios watershed in the city of Irati / Pr - Brazil.

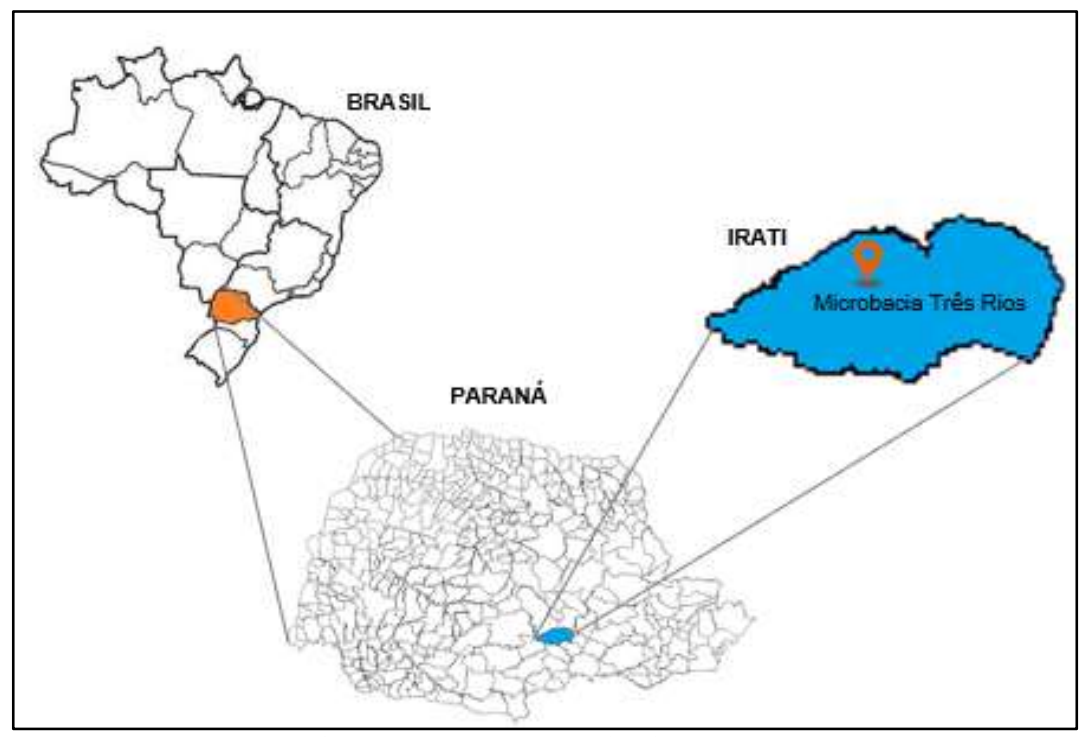

Source - THE AUTHORS (2020).

According to the Brazilian Institute of Geography and Statistics (2018), the town of Irati/PR has about 60,357 inhabitants and $999,517 \mathrm{~km}^{2}$ of territory. The town's GDP per capita is $R \$ 26,207.22$, and the average income of formal workers is equivalent to 2.3 minimum monthly wages.

Data from the SEAB (2018) show that the residents of the three communities that gathered around the micro-basin presented significant social, economic and environmental advances, which has generated decisive changes for those rural communities. Aiming to motivate these farmers, the Micro-basin Program granted them equipment to aid in their day-to-day. Moreover, the Program expects them to act as a sustainability parameter for the other rural communities of Irati/PR.

Finally, the Program also addresses the acquisition of agricultural inputs and equipment, providing water to residences through the Waters Paraná program, and integrated actions of the productive chain (SEAB, 2018).

\section{METHODOLOGY}

This paper is a descriptive study that gathered procedures and results of the Micro-basin Preservation Project in Irati, Paraná. The town was selected due to the possibility of verifying the Project's effectiveness, as well as the fact that it took place in the properties of small rural producers. The Project at hand, already described, met the specific goals of recovery and preservation of springs and settling socioeconomic matters of the rural producers.

For the literature review and paper selection, the databases ScienceDirect and the Capes Journal Portal were adopted, considering the in-depth content regarding the theme of interest, the keywords used were Micro-basins, hydrographic basins, sustainability and sustainable development. These databases were

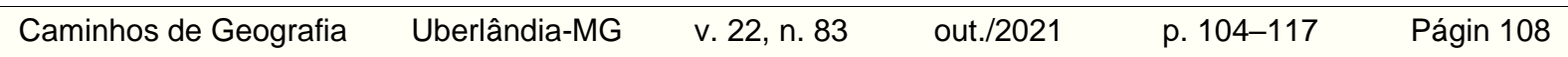


selected due to their high-impact scope of journals and their extensive bibliographic coverage of the Social Sciences field (Figueiredo et al., 2017; Norris and Oppenheim, 2007).

The searches employed the following descriptors, considering their relevance within the study's specific theme: (Micro-basins OR hydrographic basins) AND (sustainability OR sustainable development). Boolean operators were employed in the combination of search terms to increase the search sensitivity, the period of ten years (2011-2020) was adopted, and the criterion "only papers" was selected.

The process described above located a total of 466 papers. Table 1 displays their distribution.

Table 1 - Summary of the papers per search criteria.

\begin{tabular}{|c|c|c|c|}
\hline \multirow[t]{2}{*}{ Search terms } & \multicolumn{3}{|c|}{ Databases } \\
\hline & Capes & ScienceDirect & Total \\
\hline $\begin{array}{ll}\text { (Micro-basins } & \text { OR hydrographic } \\
\text { basins) AND (sustainability } O R \\
\text { sustainable development). }\end{array}$ & 441 & 25 & 466 \\
\hline \multicolumn{4}{|c|}{ Elimination Criteria } \\
\hline Duplicates & & \multicolumn{2}{|c|}{15} \\
\hline Elimination based on title & & \multicolumn{2}{|c|}{180} \\
\hline Elimination based on abstract & & \multicolumn{2}{|c|}{232} \\
\hline Elimination based on full reading & & \multicolumn{2}{|c|}{39} \\
\hline Final Portfolio of Papers & & \multicolumn{2}{|c|}{21} \\
\hline
\end{tabular}

Source - THE AUTHORS (2020).

After the search, the duplicate articles were discarded, arriving at 451 papers. Those were filtered through the analysis of titles and abstracts, resulting in 39 papers. They were read in their entirety, and the ones unrelated to the theme were eliminated. Thus, the final portfolio contained 21 papers.

Moreover, secondary data were gathered from the organs responsible for the Soil and Water Management in Micro-basins Project (IAPAR, SEAB, EMATER) and the Secretariat of Agriculture and Supply in Irati/PR. Over the investigation, the research problem showed that the research must be classified as mixed, integrating quantitative and qualitative methods to treat the data (Creswell, 2010).

Regarding technical procedures, the option selected was to conduct studies on the perception of different properties affected by the Project, that is, multiple cases. The secondary material made available by the city of Irati has an image bank about the different stages and procedures of the work developed in the Três Rios watershed, in addition to information regarding materials passed on to producers, costs, locations, targets, justifications, among others. However, such information was presented only for the view of the reader, not going through an in-depth analysis of its content, unlike what happened with the questionnaires.

The methodological triangulation was carried out searching for the research object based on different and complementary reference points in the execution of the study (Vergara, 2006). The triangulation employed four data-gathering instruments: a) document research (qualitative); b) semi-structured interviews (qualitative); c) non-participant observation (qualitative); d) questionnaires applied to the rural producers. The document research was significant to comprehend the Project and its relevance. The interviews of the rural producers were semi-structured, with the possibility of generating additional questions to the pre-established script (Dawson, 2009). The research instrument included basic information regarding the rural producer and the property, followed by specific questions directly related to the practices of preservation for each spring.

$\begin{array}{lllll}\text { Caminhos de Geografia } & \text { Uberlândia-MG } & \text { v. 22, n. } 83 & \text { out./2021 } & \text { p. 104-117 Págin } 109\end{array}$


The Project's Operative Manual (2017) suggests approximately 100 rural producers for each microbasin. In Irati/PR, the number observed was 114 families involved in the Project. Regarding the sampling process, it is considered as non-probabilistic, that is, the criteria applied were for accessibility and convenience of that moment, with the choice of elements of the population seen as qualified in the area and as an ideal source of knowledge. Thus, there were a total of 20 rural producers participating in the Program who fully answered the research questionnaire.

The data gathering in the field occurred alongside the professionals from Irati's City Hall responsible for conducting the Project. The visits occurred on several different occasions, due to their availability and the requirement of their presence. The research area included the communities Mato Queimado, Campina de Gonçalves Júnior, and Volta Grande, in the rural area of Irati/PR. The visits took place throughout August 2019, on days established with the public servants responsible for the work concerning the micro-basin.

The qualitative analysis considered the Program's Work Plan, the semi-structured interviews with the rural producers in the program, and the observation not participated by the researchers. The main variables identified at this stage are the program's goals, the actions proposed, how the rural producers learned about and were encouraged to participate in the program, and the assessment and suggestions of improvements made by them. The interviews were audio recorded and transcribed, and after the organization and preparation of the damages for analysis, a complete reading of the data was carried out and the process of coding the contents was initiated, according to the procedures described by Creswell (2010).

The quantitative analysis employed descriptive statistics of proportion, average and frequency of the variables. The role of statistics in research consists of analyzing research data, reducing it so that it can be easily read and, later, contributing to the study's conclusions (Kothari, 2004). Similarly, Marconi and Lakatos (2009), state that the statistical procedures allow to obtain from a complex set of data, simple representations, allowing generalizations by proving or not the relationships between the variables.

The correlation statistical tests were also used to measure the linear relationship between variables, which can be positively or negatively related (Field, 2009). Initially, the Shapiro-Wilk Test was performed to assess the normality of the data and with a 95\% confidence level, p-values were obtained (see Table 2):

Table 2 - Test of Normality.

\begin{tabular}{lccc}
\hline Variables & \multicolumn{3}{c}{ Shapiro-Wilk ${ }^{\mathrm{a}}$} \\
\cline { 2 - 4 } & \multicolumn{2}{c}{ Statistic } & Remarks \\
\hline Q3 - Changes & 0,719 & 0,000 & Not normal \\
\hline Q4 - Positive changes & 0,569 & 0,000 & Not normal \\
\hline $\begin{array}{l}\text { Q6 - Environmental } \\
\text { dimensions }\end{array}$ & 0,569 & 0,000 & Not normal \\
\hline Q7 - Social dimensions & & & \\
\hline Q8 - Economic dimensions & 0,262 & 0,000 & Not normal \\
\hline Q9 - Meet the objectives & 0,715 & 0,000 & Not normal \\
\hline
\end{tabular}

a. Q2 (tempo) and Q5 (pontos negativos) are constant. It has been omitted. Source - THE AUTHORS (2020).

With a result of $p<0.05$, it is concluded that the means in the questions do not have a normal distribution, the Spearman Correlation test was adopted to investigate the associations between the time of

$\begin{array}{lllll}\text { Caminhos de Geografia } \quad \text { Uberlândia-MG } & \text { v. 22, n. } 83 & \text { out./2021 } & \text { p. 104-117 Págin } 110\end{array}$


participation, changes occurred, assessment of the changes (positive or negative), adaptation to sustainability dimensions (environmental, social and economic), and overall assessment of the program. Tables and figures were employed to better display the data.

Based on the results found by the qualitative and quantitative analyses developed, the data triangulation was conducted seeking to compare and complement the information considering the several sources employed.

\section{RESULTS AND DISCUSSION}

This study was developed in the Três Rios Micro-basin, one of the beneficiaries of the Soil and Water Management in Micro-basins Program, located in the town of Irati/PR and encompassing the rural communities Volta Grande, Mato Queimado and Campina de Gonçalves Júnior (SEAB, 2018).

Data from the SEAB (2018) show that, since the residents from the three communities gathered around the micro-basin, they have had notable social, economic, and environmental advances, which has generated decisive changes in these rural communities. Aiming to motivate these farmers, the Microbasin Program granted several agricultural inputs that aid in their day-to-day. Moreover, it provided the installation of treated water systems in their residences through the Paraná Waters Program. In order to comprehend the relation of these benefits to sustainability aspects, the changes and the impacts generated by the Program for the participating farmers were analyzed.

The first variable analyzed is the time of participation in the Program. 95\% of the respondents have been participants for over two years and 5\% (one respondent) has been a part of the Program for over one year. Therefore, the participants have had enough time to learn how it functions and understand the benefits and impacts generated.

They learned about the Program through announcements made by the agencies connected to agricultural services. The methods most mentioned by the interviewees are the technician visits to the properties and the community meetings organized by professionals of the area.

The presence of technicians is the most recurring answer in the interviews as a method of joining the Program, occurring through technician visits to the residences of interested producers. Among the 20 respondents, 11 (55\%) directly mentioned Emater or its technicians as incentives to join the Program. All respondents mentioned the presence of technicians in the presentation of the Program, not specifying whether they were professionals from the Town Secretariat of Agriculture or Emater. The introduction made by people backed by their instruction in the area related to the theme seems to influence the adhesion of farmers.

The technicians went to the residences of producers interested in participating in the Micro-basin Program. Moreover, they organized meetings with the associations of residents of the communities in question. These publicized the Program.

Figure 2 - Changes Caused by the Soil and Water Management in Micro-basins Program.

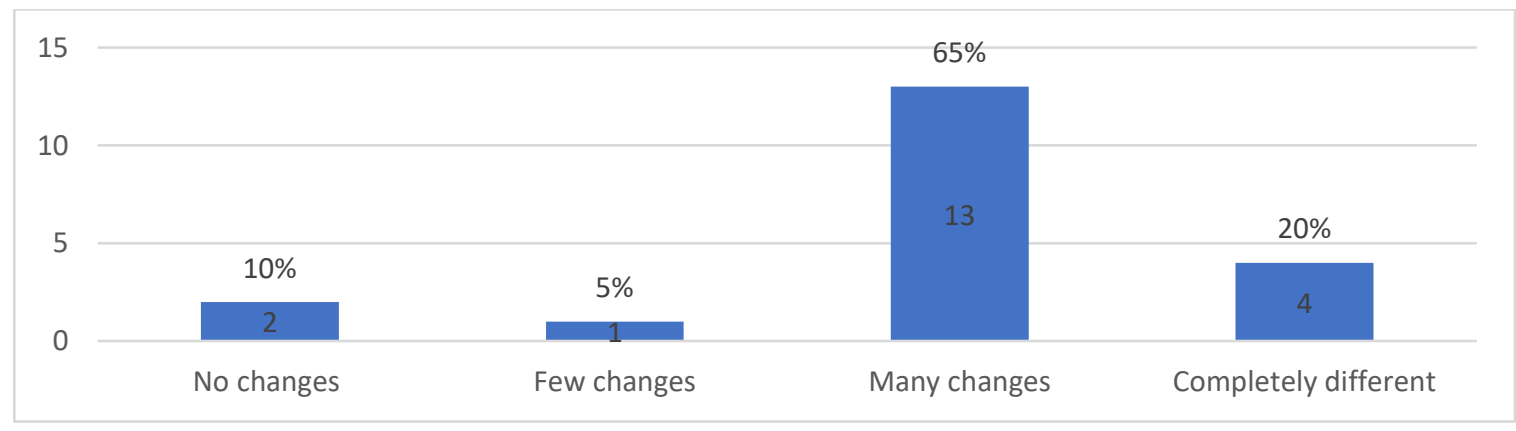

Source - RESEARCH DATA (2020).

Caminhos de Geografia Uberlândia-MG v. 22, n. $83 \quad$ out./2021 p. 104-117 Págin 111


Among the respondents, $85 \%$ acknowledge the existence of significant changes (many and completely different). Only $15 \%$ declared that few or no changes occurred. It is noticeable that the rural producers consider that the implementation of the Program has entailed changes.

Figure 3 displays the perception of the respondents regarding the Program as positive or negative.

Figure 3 - Perception of the rural producers regarding the changes caused by the Soil and Water Management in Micro-basins Program.

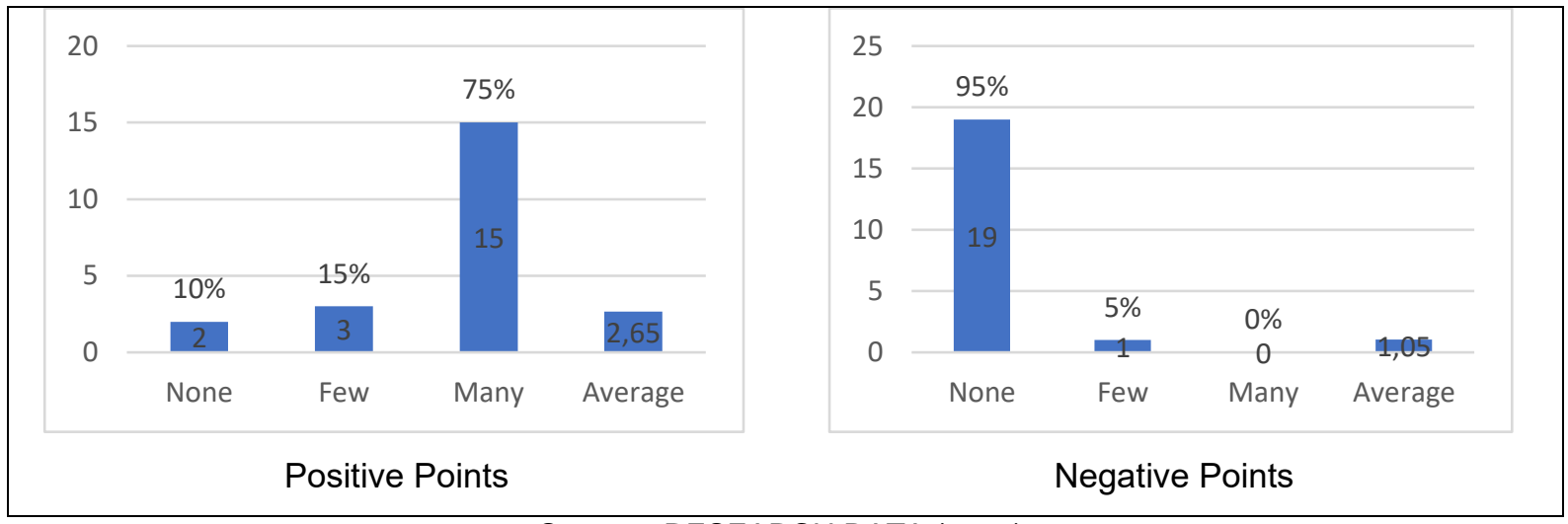

Source - RESEARCH DATA (2020).

The data show that the rural producers participating in the Program acknowledge that the benefits are numerous ( $75 \%$ of the respondents). The average, on a 3 -point scale, is 2.65 , which illustrates the recognition of the changes as positive.

Regarding negative impacts, $95 \%$ of the interviewees state that they were non-existent. The average is 1.05 , very close to 1 , the lowest value in the scale.

The analysis of these elements demonstrates that changes take place with the implementation of the Soil and Water Management in Micro-basins Program and that they are regarded as positive by the rural producers. This illustrates the positive perspective concerning the transformations caused by the Program, recovering and preserving the springs that it encompasses.

The analysis of the work plan of the Program proposed by the Town Secretariat of Agriculture of Irati/PR observed that the changes concern matters of technical improvement, seeing that among the eight goals proposed, four (50\%) concern enhancements in production conditions. Goals 04,05 and 08 concern the installation and waste treatment related to livestock (manure tanks, distribution of liquid manure as fertilizer, and installation of floors in the waiting area of milk production). Goal 07 is the acquisition of limestone for soil fertilization.

These improvements can also bring social benefits through the organization of collective use inputs, such as the use of the liquid manure distributor and the community water supply. Still concerning social goals, the program affords better sanitation conditions by providing treated water to the residences through community water supplies (goal 01).

Considering these goals, the waste treatment related to livestock raising is one of the environmental benefits. The use of manure tanks is a technique recommended to put livestock waste to use, which entails less environmental pollution.

Other three goals are directly connected to environmental benefits. Goals 02 and 03 seek to provide materials to protect and recover springs, as well as to isolate those areas. Goal 06 aims to apply machine-hours in terracing, a technique that avoids soil erosion and consequently protects rivers and springs. The benefits can be observed directly.

In order to comprehend how the Program's proposal is aligned with the sustainability triple bottom line in its economic, social, and environmental dimensions, the perception of the participating rural producers regarding those dimensions was assessed, as shown in the table below.

$\begin{array}{lllll}\text { Caminhos de Geografia } & \text { Uberlândia-MG } & \text { v. 22, n. } 83 & \text { out./2021 } & \text { p. 104-117 }\end{array}$


Table 3 - Assessment of Sustainability Dimensions.

\begin{tabular}{|c|c|c|c|c|c|c|}
\hline & \multicolumn{2}{|c|}{$\begin{array}{c}\text { Environmental } \\
\text { Benefits }\end{array}$} & \multicolumn{2}{|c|}{ Social Benefits } & \multicolumn{2}{|c|}{ Economic Benefits } \\
\hline & Resp. & Perc. & Resp. & Perc. & Resp. & Perc. \\
\hline No benefits (1 point) & 2 & $10 \%$ & 1 & $5 \%$ & 4 & $20 \%$ \\
\hline Few benefits ( 2 points) & 3 & $15 \%$ & 0 & $0 \%$ & 5 & $25 \%$ \\
\hline Many benefits ( 3 points) & 14 & $70 \%$ & 17 & $85 \%$ & 11 & $55 \%$ \\
\hline Did not know how to answer & 1 & $5 \%$ & 2 & $10 \%$ & 0 & $0 \%$ \\
\hline Average & 2.63 & & 2.89 & & 2.35 & \\
\hline
\end{tabular}

Source - THE AUTHORS (2020).

Table 3 shows that, among the sustainability dimensions on a scale of 1 to 3 , the highest average is for social benefits ( 2.89 points), followed by environmental benefits ( 2.63 points). The lowest average among the dimensions is of economic benefits (2.35 points). The respondents perceive greater social and environmental benefits in the Program than economic ones. The perceptions gathered illustrate that the results of the socio-environmental goals were more evident and translate the success of the Program's proposal, which, in a way, puts more emphasis on solving social and environmental problems.

Thus, it is possible to conduct a more precise analysis of the dimensions related to the Program's goals. The farmers recognize the environmental benefit of water conservation and the social benefit of community water supply, for instance. However, they question the fulfillment of their economic interests. Even though it is a dimension addressed by the Program, the wishes of the rural producers are not completely met. Regarding possible improvements in the Program, the respondents mention road improvements (cited by three interviewees, that is, $15 \%$ of the sample) to better transport the production, better division of resources among the beneficiary families, and linking their reality to better planning in the Program's actions (mentioned by five respondents - 25\%). Of 20 interviewees, eight $(40 \%)$ point out the need for a few improvements. Other ten respondents (50\%) are satisfied with the Program.

It is worth stressing that three respondents (15\%) mentioned the need for more community engagement by the rural producers to improve the Program's actions, a need for enhancing the association-minded behavior.

However, when assessing the Program objectively overall, the farmers regard it as satisfactory, as shown in Figure 4.

Figure 4 - Overall Assessment of the Program.

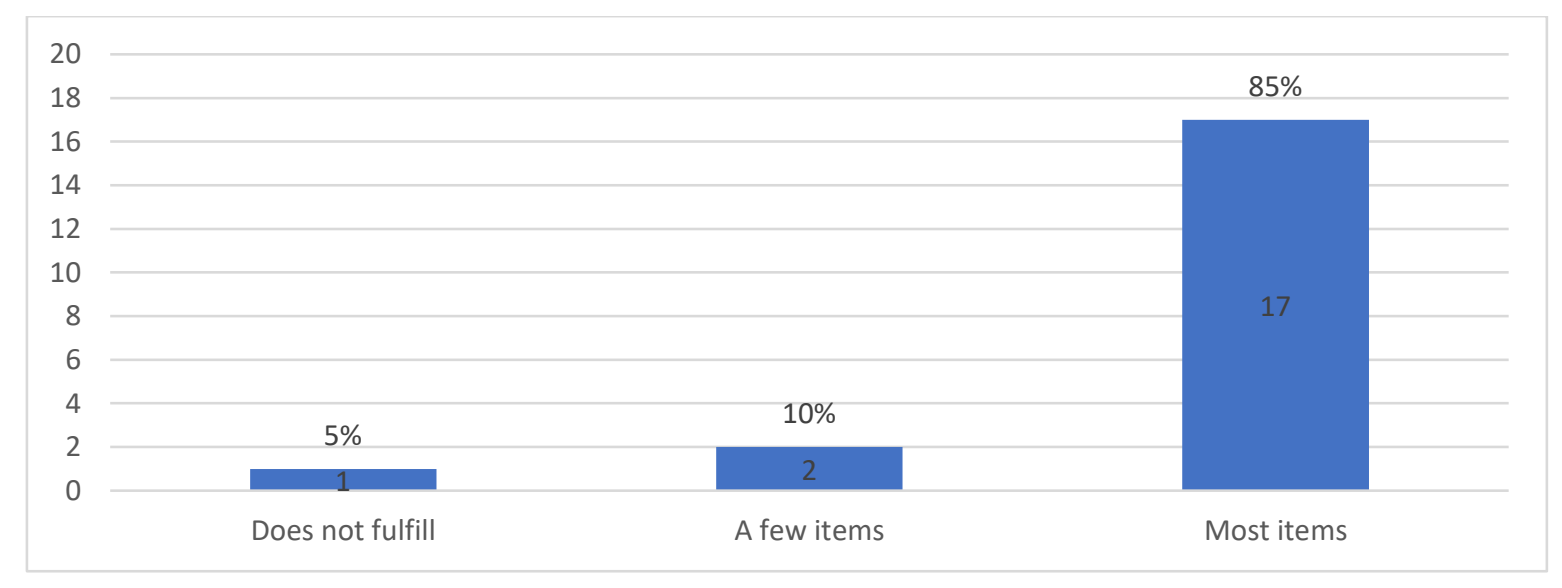

Source - THE AUTHORS (2020).

Regarding the fulfillment of the proposal, $85 \%$ of the respondents agree that the Program achieves its goals. Only one interviewee (5\%) states that it does not fulfill its proposal. The results illustrate the

$\begin{array}{lllll}\text { Caminhos de Geografia } & \text { Uberlândia-MG } & \text { v. 22, n. } 83 & \text { out./2021 } & \text { p. 104-117 }\end{array}$


acknowledgment of the Program's effectiveness, despite the considerations on the alignment of the producers' wishes with the Program's goals.

The correlation of the responses given by the producers corroborates the presented analyses, as shown in the objective data displayed in the correlation matrix in Table 4.

Table 4 - Correlation Matrix with Spearman test.

\begin{tabular}{|c|c|c|c|c|c|c|c|}
\hline & $\begin{array}{l}\text { Q6. } \\
\text { Environmental } \\
\text { benefits }\end{array}$ & $\begin{array}{l}\text { Q7. Social } \\
\text { benefits }\end{array}$ & $\begin{array}{l}\text { Q8. } \\
\text { Economic } \\
\text { benefits }\end{array}$ & $\begin{array}{l}\text { Q9. } \\
\text { Program } \\
\text { fulfills } \\
\text { goals }\end{array}$ & $\begin{array}{l}\text { Q3. } \\
\text { Changes } \\
\text { occur }\end{array}$ & $\begin{array}{l}\text { Q4. } \\
\text { Changes } \\
\text { are } \\
\text { positive }\end{array}$ & $\begin{array}{l}\text { Q5. } \\
\text { Changs } \\
\text { are } \\
\text { negative }\end{array}$ \\
\hline $\begin{array}{l}\text { Q6. } \\
\text { Environmental } \\
\text { benefits }\end{array}$ & 1 & $00.551^{*}$ & $0.539^{*}$ & $0.787^{\star \star}$ & $0.681^{* *}$ & $0.788^{* *}$ & $-0.474^{*}$ \\
\hline $\begin{array}{l}\text { Q7. Social } \\
\text { benefits }\end{array}$ & $0.551^{*}$ & 1 & 00.403 & $0.728^{* *}$ & $0.477^{*}$ & $0.548^{*}$ & \\
\hline $\begin{array}{l}\text { Q8. Economic } \\
\text { benefits }\end{array}$ & $0.539^{*}$ & 00.403 & 1 & $0.645^{* *}$ & $0.617^{* \star}$ & 00.385 & -00.353 \\
\hline $\begin{array}{l}\text { Q9. Program } \\
\text { fulfills goals }\end{array}$ & $0.787^{* *}$ & $0.728^{* *}$ & $0.645^{* *}$ & 1 & $0.541^{*}$ & $0.786^{* *}$ & $-0.512^{*}$ \\
\hline $\begin{array}{l}\text { Q3. Changes } \\
\text { occur }\end{array}$ & $0.681^{* *}$ & $0.477^{*}$ & $0.617^{* *}$ & $0.541^{*}$ & 1 & 00.337 & -00.423 \\
\hline $\begin{array}{l}\text { Q4. Changes } \\
\text { are positive }\end{array}$ & $0.788^{* *}$ & $0.548^{*}$ & 00.385 & $0.786^{* *}$ & 00.337 & 1 & $-0.472^{*}$ \\
\hline $\begin{array}{l}\text { Q5. Changes } \\
\text { are negative }\end{array}$ & $-0.474^{*}$ & . & -00.353 & $-0.512^{*}$ & -00.423 & $-0.472^{*}$ & 1 \\
\hline
\end{tabular}

As previously assessed, the fulfillment of the Program's goals is more strongly related to environmental (positive correlation of 0.787 ) and social issues (positive correlation of 0.728 ) than economic ones (positive correlation of 0.645 ).

Environmental issues are also correlated to the acknowledgment of changes (positive correlation of 0.681 ), and those changes are recognized as positive (positive correlation of 0.788 ).

These indicators show that the rural producers aided by the Program acknowledge the fulfillment of its purpose of environmental water conservation in the micro-basin at hand. The Program has generated impacts in the community, and the changes are clearly recognized.

In general, the findings of this research corroborate with other studies referring to projects already implemented, such as PNMH (National Watershed Project), PMISA (Integrated Soil and Water Management Project), Paraná Rural Program which aimed, in a satisfactory way, promote planning and occupation of rural areas to achieve a sustainable increase in production and productivity, in addition to improving the level of income and living conditions of the Brazilian rural population. It is also worth mentioning the important participation of trained professionals who accompanied and guided the projects.

In this way, the Microbasin projects were being improved because the problems encountered with water management were hierarchized, stimulating the participation in an integrated manner of all the actors directly related to the goals of environmental sustainability. Thus, the management of natural resources in microbasins has consequently become a "socio-environmental management", acquiring increasing sophistication, technique and operational complexity.

$\begin{array}{lllll}\text { Caminhos de Geografia } & \text { Uberlândia-MG } & \text { v. 22, n. } 83 & \text { out./2021 } & \text { p. 104-117 Págin } 114\end{array}$




\section{FINAL CONSIDERATIONS}

This paper investigated the effectiveness of one of the Projects belonging to the Recovery and Revitalization of Micro-basins Program in the State of Paraná, which involves several state agencies in different towns, from a sustainability perspective. The study found that the Project described above achieved significant effectiveness in its results, illustrating a public policy that worked. The initiative, a joint effort of the State and the town of Irati/PR, achieved through the Project significant improvements in the socio-environmental conditions of a group of small rural producers, who identified clear advances in these two sustainability areas.

The findings also showed that the initial economic advances have not yet been fully realized. However, it should be noted that, on several occasions, economic results do not occur immediately, and the socioenvironmental improvements are evident and bring seldom-observed conditions in groups of small rural producers. The possibility of access to social benefits, such as treated water and waste collection and treatment, is very uncommon in certain contexts, and by itself vastly improves the living conditions of the 114 producers of the region reached by this Project.

This investigation definitely supports the perspective that it is possible for a public program, through a project that involves different agents, to have positive results and act as a reference for other projects of similar nature. In this situation, no embezzlement or poor application of public resources were encountered, which illustrates that well-designed projects supported by committed public agents achieve remarkable results. In other words, it is possible to attain excellent results through well-planned and properly-executed public policies.

This work does not exhaust the theme, nor does it reflect the Program's results as a whole; future investigations are possible. For instance, pondering on the investment made and the results obtained. However, it demonstrates that it is possible to carry out significant and effective public policies, which bring undeniable benefits to small rural producers that would not be obtained otherwise. The initiative makes life in small rural properties viable, avoiding rural flight and providing better living conditions to a population that needs initiatives of this nature.

It is rather common to observe unsuccessful policies. However, it is also fundamental to point out when initiatives solve complex problems such as the region of the micro-basin investigated, which presented social, environmental, and economic issues. In an increasingly more complex context that demands unusual solutions, effective results based on sustainability and TBL balance are crucial for the belief that the necessary transformations are possible and attainable.

\section{REFERENCES}

ADHAMI, M. et al. Best soil comanagement practices for two watersheds in Germany and Iran using game theory-based approaches. Science of the Total Environment. v.698, n.1, p. 1-13, 2020. https://doi.org/10.1016/j.scitotenv.2019.134265

ATTANASIO, C. M. et al. A importância das áreas ripárias para a sustentabilidade hidrológica do uso da terra em microbacias hidrográficas. Bragantia, v. 72, n.4, 2012. https://doi.org/10.1590/S0006-87052013005000001

BLACKBURN, W. R. The Sustainability Handbook: the complete management guide to achieving Social, Economic and Environmental Responsability. Cap. 1, 2 e 3. London: Earthscan, 2007.

BARBIERI, J. C. Desenvolvimento e meio ambiente: as estratégias de mudanças da Agenda 21. 4ํe ed. Petrópolis: Vozes, 2001.

BARDIN, L. Análise de conteúdo. São Paulo: Edições 70, 2011.

BECKER, B. et al. Geografia e meio ambiente no Brasil. São Paulo: Hucitec, 1995.

CAMARGO, A. Governança para o século 21. In: TRIGUEIRO, A. (org). Meio ambiente no século 21. Rio de Janeiro: Sextante, 2003.

$\begin{array}{lllll}\text { Caminhos de Geografia } & \text { Uberlândia-MG } & \text { v. 22, n. } 83 & \text { out./2021 } & \text { p. 104-117 Págin } 115\end{array}$


CARVALHO, J. R. M de. et al. Proposta E Validação De Indicadores Hidroambientais Para Bacias Hidrográficas: Estudo De Caso Na Sub-Bacia Do Alto Curso Do Rio Paraíba, Pb. Soc. \& Nat. v.23, n.2, 2011. https://doi.org/10.1590/S1982-45132011000200012

CHRISTOFOLETTI, A. Modelagem de sistemas ambientais. Edgard Blücher, 1999.

COHEN, E.; FRANCO, R. Políticas Sociais, racionalidade e avaliação. Avaliação de projetos sociais. Rio de Janeiro: Vozes, p. 19-37, 1993.

COMISSÃO MUNDIAL SOBRE MEIO AMBIENTE E DESENVOLVIMENTO (CMMAD). Nosso futuro Comum. 2. ed. Rio de Janeiro: FGV, 1991.

CRESWELL, J. W. Projeto de pesquisa: métodos qualitativo, quantitativo e misto. Porto Alegre: Artmed, 2010.

DAWSON, C. Introduction to research methods: a practical guide for anyone undertaking a research project. United Kingdom: How to Books, 2009.

DE PAULA, J. A. Biodiversidade, população e economia. Uma região de Mata Atlântica. CEDEPLAR, UFMG, Belo Horizonte. 672p, 1997.

EMATER - Empresa Paranaense de Assistência Técnica e Extensão Rural. Disponível em: http://www.emater.pr.gov.br/modules/conteudo/conteudo.php?conteudo=56 . Acesso em 14. mar. 2020.

ELKINGTON, J. Partnerships from cannibals with forks: The triple bottom line of 21 st-century business. Environmental quality management, v. 8, n. 1, p. 37-51, 1998.

https://doi.org/10.1002/tqem.3310080106

FEDERAL, Brasil Senado. Conferência das Nações Unidas sobre meio ambiente e desenvolvimento: a Agenda 21. In: Conferência das Nações Unidas sobre meio ambiente e desenvolvimento: a Agenda 21. 1996.

FIELD, A. Descobrindo a estatística usando o SPSS (tradução Lorí Viali), 2. ed. Porto Alegre: Artmed, 2009.

FIGUEIREDO et al. Estudo da eficiência dos portais ScienceDirect, Scopus, Lilacs e Periódicos CAPES, evidenciando seus aspectos positivos e negativos. Scientia Amazonia, v. 6, n.2, p.1-10, 2017.

IBGE - Instituto Brasileiro de Geografia e Estatística. Disponível em: https://cidades.ibge.gov.br/brasil/pr/irati/pesquisa/24/76693 . Acesso em 14. mar. 2020.

JUNIOR, J. H. P; FERRÃO, A. M. A. Aspectos de gestão integrada de bacias hidrográficas. Cidades, v.37, n.1, 2018.

KOTHARI, C. R. Research methodology: methods and techniques. 2ed. New Delhi: New Age International Publishers, 2004.

LUIZ, T. B. P. et al. Mapeamento de risco de sodificação de solos em microbacia hidrográfica no Rio Grande do Sul. Revista Verde de Agroecologia e Desenvolvimento Sustentável, v. 12, n.1, 2017. https://doi.org/10.18378/rvads.v12i1.4390

MAGALHÃES, R. C; BARP, A. R. B. Inovações metodológicas para construção de cenários estratégicos em bacias hidrográficas. RAI Revista de Administração e Inovação, v. 11, n. 3, p. 200226, 2014. https://doi.org/10.11606/rai.v11i3.100221

MAIGNAN, I; RALSTON, D. A. Corporate social responsibility in Europe and the U.S.: Insights from businesses' self-presentations. Journal of International Business Studies, v.33, n.1, 2002. https://doi.org/10.1057/palgrave.jibs.8491028

MARCONI, M. A.; LAKATOS, E. M. Fundamentos de metodologia científica. 6 ed. São Paulo: Atlas, 2009.

$\begin{array}{lllll}\text { Caminhos de Geografia } & \text { Uberlândia-MG } & \text { v. 22, n. } 83 & \text { out./2021 } & \text { p. 104-117 }\end{array}$


MENGISTU, F; ASSEFA, E. Farmers' decision to adopt watershed management practices in Gibe basin, southwest Ethiopia. International Soil and Water Conservation Research. v.7, n.1, p.376-387, 2019. https://doi.org/10.1016/j.iswcr.2019.08.006

MUNDIAL, Banco. Globalização, crescimento e pobreza. São Paulo: Futura, 2003.

NORRIS, M.; OPPENHEIM, C. Comparando alternativas para cobertura da literatura das ciências sociais. Journal of Informetrics, v. 1, n. 2, p. 161-169, 2007. https://doi.org/10.1016/i.joi.2006.12.001

NOVAES, Washington. Agenda 21: um novo modelo de civilização. MMA, 2003.

PFEIFFER, P. Gerenciamento de projetos de desenvolvimento: conceitos, instrumentos e aplicações. Brasport, 2005.

PMI, PROJECT MANAGEMENT INSTITUTE. The nature of International Development Projects: definition, what are International Development (ID) Projects? Project Management Institute Inc., 2003a. Disponível em: http://www.pmi-idsig.org/ . (acesso em 25/02/2020).

POTTS, D. Project planning and analysis for development. Lynne Rienner Pub., 2002.

RHODEN, A. C.; FELDMANN, N. A.; MUHL, F. R.; RITTER, A. F. S.; MOREIRA, A. A importância da água e da gestão dos recursos hídricos. Revista ciências agroveterinárias e alimentos, n.1. v.1, 2016.

ROSS, J. L. S; DEL PRETTE, M. E. Recursos hídricos e as bacias hidrográficas: âncoras do planejamento e gestão ambiental. Revista do departamento de geografia, v. 12, p. 89-121, 1998. https://doi.org/10.7154/RDG.1998.0012.0005

SACHS, I. Estratégias de transição para o século XXI: desenvolvimento e meio ambiente. Studio Nobel, Fundação do Desenvolvimento Administrativo, 1993.

SEAB - Secretaria da Agricultura e do Abastecimento. Disponível em:

http://www.agricultura.pr.gov.br/modules/conteudo/conteudo.php?conteudo=28 . Acesso em 14. mar. 2018.

Secretaria de Estado da Agricultura e do Abastecimento. Manual Operativo do Projeto. 2017. Disponível em:

http://www.agricultura.pr.gov.br/arquivos/File/deagro/microbacias/mop microbacias 0704 2017.pdf . Acesso em 14. mar. 2018.

SILVA, A. P; SILVA, C. M. Planejamento Ambiental Para Bacias Hidrográficas: Convergências E Desafios Na Bacia Do Rio Capibaribe, Em Pernambuco-Brasil. HOLOS, v.30, n. 1, 2014. https://doi.org/10.15628/holos.2014.1734

STEFANO, S. R.; TEIXEIRA, G. Desenvolvimento sustentável nas organizações: programas do Banco do Brasil. Revista Competitividade e Sustentabilidade, v.1, n.3, p.46-61, jan./dez. 2014. https://doi.org/10.5935/2359-5876.20140004

TUCCI, C. E. M. Desenvolvimento dos recursos hídricos no Brasil. Global Water, 2004.

TUNDISI, José Galizia. Água no século XXI: enfrentando a escassez. RIMA, IIE: 2003.

VERGARA, S. C. Métodos de pesquisa em administração. São Paulo: Atlas, 2006.

YIN, R. K. Estudo de caso: planejamento e métodos. Porto Alegre: Bookman, 2010.

ZOLLO, M.; CENNAMO, C.; NEUMANN, K. Beyond What and Why. Organization \& Environment,v.26, n.3, p.241-259, 2013. https://doi.org/10.1177/1086026613496433

Recebido em: 17/07/2020

Aceito para publicação em: 24/11/2020 